This technique is extremely interesting as it offers students the possibility of working with translations and equivalences in all directions, which will enable them to develop their linguistic skills in a considerable way.

Another very relevant aspect about this reference book is that it does not only give a list of terms but also offers some very useful additional sections in which the author completes his contribution. One of them deals with formulas and typical expressions in commercial letters, for which the equivalences with Catalan and Spanish are provided. The other additional section is equally worthy of mention, as it will be very much appreciated by students as well as teachers. Miquel Àngel Campos Pardillos has gathered a series of common mistakes made by students, and explains why they appear and at the same time gives hints that can be helpful to avoid them.

These last two sections further reinforce the conception that is clearly behind this work, the author's didactic aim. As a lecturer in Commercial English at the University of Alicante, the author very well knows the problems and needs of his students, and decidedly faces them making a very important contribution in the form of an instrument to improve their level of English that certainly achieves all its objectives and which, I am sure, students will be thankful for.

Finally, it must also be said that, since the author has used both Spanish and Catalan, this dictionary can go well beyond the academic context and will surely become a useful reference material for the Civil Service both in Spain as a whole and in the context of the autonomous regions in which Catalan is used; besides, it will no doubt be a very useful tool for all kinds of enterprises, specially those which are involved in export-import trade.

Víctor Manuel Pina Medina

\title{
Hayden White. Metahistory: The Historical Imagination in Nineteenth-Century Europe. Baltimore: Johns Hopkins UP, 1973, 448 pp. - Hayden White. The Content of the Form: Narrative Discourse and Historical Representation. Baltimore: Johns Hopkins UP, 1987, 244 pp.
}

Although fourteen years have elapsed between the two works reviewed here, the purpose of them both still remains unaltered. Along with Louis O. Mink and Paul Ricoeur, Hayden White is today a most outstanding instance of the contemporary tendency to regard narrative as the fundamental form of historical construction and understanding - that is, the inclination to regard history less as a manner of representing reality than as a way of telling as well as of organizing events. Although this view, which can also be observed in the works of other theorists such as Jean-François Lyotard, in some sense partakes of the postmodern thrust to conceive reality as textually (or discursively) construed, his purpose is more humanistic than deconstructive. In fact, White withdraws himself from many forms of postmodern "pantextualism" insofar as he preserves the differences between reality and fiction, on the one hand, and between fiction and history, on the other. This enables him to study historiography-and its relation to culture-with a more encompassing method than many critics (Derrida, Foucault, or Hillis Miller, for instance), 
that is, with more recourse to "reality" and extratextual matters than many contemporary thinkers are willing to concede.

Metahistory offers us an extensive and thoroughgoing exploration of the historical imagination in 19th-century Europe, that is, an analysis of the historical method as put forward by different historians, philosophers and social theorists from Hegel to Croce. What makes White's book differ brilliantly from others of the same kind is the fact that he works through the different ideas of history and, at the same time, succesfully studies the ideological validations they enjoyed in their time. This turns Metahistory into a study not only of historical consciousness but also an exploration of history as a mode of cognition and emplotment. White's work begins by establishing "realism" as the guiding principle for the different modes of historical writing in the 19th century-exemplified by Michelet, Ranke, Tocqueville and Burckhardt. The late part of the century is characterized-as set forth in the writings of Marx, Nietzche and Croce-by the repudiation of realism in historical consciousness. In White's formulation, it is metaphor, metonymy, synecdoche, and irony- "the basic types of linguistic prefiguration"-that articulate the four theories of truth-making in historical understanding found in the late 19th century (Formism, Mechanism, Organicism, and Contextualism). Hence White's distinction of four "strategies of ideological implication by which historians can suggest to their readers the import of their studies of the past for the comprehension of the present": Anarchism, Radicalism, Conservatism, and Liberalism (427).

On the other hand, gathering essays written throughout the first half of the 1980s, The Content of the Form maintains this same perspective of historical imagination as narrative, enlarging its scope to embrace contemporary forms of historical understanding-Jameson, Foucault and Ricoeur, among others; but in this case, the study of narrativity is not only confined to historical discourse. It is here that White's inquiry reaches its profoundest implications for cultural history. Here his analyses, while still showing how narrative organization is the way by which historical events are given shape, draw on the more general principle that narrative is not only a foundational element of historiography, but of cultural reality and human life in general. In so doing, White attempts to reach (and actually attains, I think) an anthropological, transcultural element in the configuration not only of history but also of culture itself.

Ricardo Miguel Alfonso

Víctor Manuel Pina Medina. La idiomaticidad en el lenguaje literario: estudio basado en la novela On the Road de Jack Kerouac en sus versiones inglesa, castellana y francesa. Alicante: Secretariado de Publicaciones de la Universidad de Alicante, 1993.

As the author reminds us at the very beginning, "linguistics and literature have ignored each other for many years." Traditionally, the two main domains of what is loosely called in Spanish "philology" (filologia) have not worked together as they should, thus forcing any would-be scholar to a painful, unavoidable choice, placing us at a meaningless 